\title{
Fragment v romantické poezii
}

\author{
Hana Voisine-Jechova (Paříž)
}

V literatuře nejsou lidské osudy zobrazeny objektivně, ve sledu událostí, v kterých proběhly, ba i vzpomínka na ně je $\mathrm{v}$ jistém smyslu nevěrná, nebot se do ní mísí i jiné zážitky, byt často okrajové a bezděčné. Je ostatně mnoho „romantismů“, nebot každý z nich částečně respektuje tendence, které jej reprezentují, ale zároveň je přesahují. Přesto však mají určité rysy, které umožňují jejich srovnání.

Jedním z charakteristických rysů romantismu je fragment, který není pouze nedopověděním věty (nebo i slova), ale je i výrazem toho, co vlastně nelze plně vyjádřit. Fragment má mnoho funkcí, někdy i podvojných nebo vícevrstvových, a bylo by obtížné všechny vyjmenovat. Autor z důvodů osobních i jiných dílo nedokončil. Ale vedle toho existuje $\mathrm{i}$ fragment, třeba $\mathrm{i}$ více fragmentů, často spolu spojených, ale zároveň zachovávajících svou svébytnost, které sugerují určitý vztah k dílu, ale pro které jazyk není dostatečně uzpůsoben.

Jazyk je především nástroj sdělení a výrazu, zachycuje to, co lze definovat. Tato definice je však překročena, byt nelze v mnoho případech přesně zachytit „ohlasy“, které se za ni skrývají. Vědomí člověka přesahuje schopnost jeho vyjádření - i hledají se cesty, jak s tím zápolit. Vznikají metafory obecně užívané a které už nikdo nevnímá a tento druh se stále obohacuje - ale ve většině případů často zaniká nebo se spojuje s definovatelnými přirovnáními. Stále znova a znova se jazyk pokouší pojmenovat věci, pro které není definice. Ale vedle toho jsou i ,„mlčení“, za kterými se vyjádřuje to, co nelze zachytit slovy.

Jedním z př́kladů je Máchova „zpověd““, kterou „slyšiı“ pouze jeho žalářník - ale je neschopen ji vyjádřit slovy. Odrazí se však v jeho vědomí, nebo spíše v podvědomí. Lidský „cit“ je důležitější (nebo spíše širší). Poutník je vyzván,

1 Dílo Karla Hynka Máchy. Svazek první. Praha: Fr. Borový, 1948, s. 12. aby se ptal mnichů... Ale nač se jich může ptát? Hledá odpověd'? Ale nemá ji sám v sobě? Skončí v bystřině, ale nepatří do sféry sebevrahů. Mezi činem a jeho přičinou zůstává jakási mezera. Osudy postav nejsou vysvětleny, ba ani vysvětleny být nemohou.

Vytváří se obraz, který je a není neskutečný. V básni Dobrou noc „Větřik zdychne v harfy li̊no dutě “, zůstává pouze část výpovědi, za kterou se otevírá tázání. Bylo by absurdní na toto tázání odpovídat, nelze je přesně definovat, uvádí do sféry pocitů protichůdných, ale zároveň harmonicky propojených (harfa, struny, zvuky - od přesného výrazu / harfa/ se přechází k jeho účelu /struny/ a $\mathrm{k}$ výsledku na lidské pocity / $z v u k y /$. Jenže „toto lůno je duté“ a „struny žádné nemá“.

Jde o výraz „dvoudomý“, kde tvrzení je zároveň popíráním toho, co je sdělováno. Romantická poezie je založena na protikladech, a to nejen po stránce tematické, ale i v pojetí stylistickém.

\section{Tematické přerývání mezi následky a jejich príčinami}

Následky nebývají rovnoměrně s př́ičinami, a to především v romantismu, kdy je důraz na vykonání činu (často i zločinu, byt někdy bezděčného) mnohem výraznější než podmínky, za kterých byl spáchán. Provinilec jedná spontánně, mnohdy i bezděčně, nebo si neuvědomuje dosah svých činů. Logické myšlení je nahrazeno impulzem nebo spíše nedefinovatelným popudem, někdy i vnitřně protilehlým. $Z$ toho vyplývá určitá fragmentárnost výrazu. Každá představa je na jedné straně izolována od kontextu, zachovává si vlastní podobu - bez ohledu na její zařazení do harmonického uspořádání díla. Zároveň však tvoří součást celkového vyznění textu.

Jde ostatně o široký proud literárního pojetí, který se v různých proměnách objevuje ve všech 
směrech, odklánějících od realistického chápání tvorby, a to nejen $\mathrm{v}$ textech inspirovaných poezií umělou, ale i v dílech ohlasových, vyrůstajících z prostředí lidové slovesnosti. Může se řadit do fragmentárního zobrazení motivů bez vnitřní spojitosti, jak tomu bývá v národních písních, kde téma vina na bílém beránku nemá nic společného s modrookým Jankem.

\section{Zdůraznění určitých činů (často zločinu) na úkor logického plynutí času}

Každá epocha si vytváří svůj repertoár motivů, který obměňuje ve spojení s literárním žánrem. $\mathrm{V}$ romantismu jde o zdůraznění výrazu, někdy až na pomezí nebo i v duchu zpovědi, kdy identita mluvčího je důležitější než jeho vnější osudy. Důraz je na rozpornosti lidských osudů. Jde o psychologické prohloubení pojetí člověka, který se v romantismu stal představitelem vnitřně dvoudomého vědomí i svědomí. Literární výraz probíhá vertikálně, jeho horizontální podmínky jsou oslabeny. Často má charakter jednotlivých fragmentů, kde prŕčiny jejich spojitosti nejsou vysvětleny.

$\mathrm{V}$ rámci kontrastního zobrazení je důraz položen i na volbu postav. Jsou to, většinou výjimeční, jedinci mladíci nebo starci, vzpomínající na své mládí, které bylo poznamenáno zklamáním a zločinem, které je nutno i po letech odpykat. Mezi činem a jeho potrestáním, byt problematickým, čas není měřen, jako kdyby neexistoval.

prof. PhDr. Hana Voisine-Jechova, CSc.

Pařǐž, Francie

hanavois123@hotmail.com 